ond abdominal segment, as well as in the plainly undivided radial cell and curved discoidal vein in the hind wing.

Liobracon cressonii $\mathrm{D}$. T.

Cresson, Proc. Ent. Soc. Philadelphia, Vol. 4, p. 75. (1865.) (Bracon distinctus.)

Dalla Torre, Cat. Hym., Vol. 4, p. 264. (1898.) (Bracon cressonii.)

Dr. Mann took this species in Hayti at Cape Haytien, Grand Rivière and St. Marc.

\title{
SOME OBSERVATIONS ON THE WEBBING CLOTHES MOTH (TINEOLA BISELLIELLA HUM.). .
}

\section{By M. T. Smulyan,}

U. S. Bureau of Entomology, Melrose Highlands, Massachusetts.

Two larvæ, 7 and $11 \mathrm{~mm}$. long, respectively, discovered working in the writer's overcoat October 25,1917 , were placed in a glass jar lined, except at the top, with a layer of gray felt, and placed in his sleeping room where his clothes-closet was located, for rearing and observation. The room was then receiving, and continued to do so until well into April, some furnace heat during the day, but was quite cool during the night and early forenoon, when it was freely ventilated. Owing to the writer's regular duties, most of the observations dealing with the behavior of the larvæ were made at the close of the day, by artificial light-which, as will be seen below, may have had a bearing on the behavior of one of them.

October 28, both larvæ feeding freely. November 1, the smaller within a substantial cocoon, at the bottom of the jar. November 2, had moulted - found the cast shell of the head just outside the cocoon, at one end, and the remainder of the skin just outside at the opposite end-but when the jar was brought closer to the light (gas) in order to verify the observation, the larva hurried out of the cocoon and crawled away. November 4, the same individual in the process of constructing another cocoon; the other-the largerwas still feeding freely. November 7 , found the latter encased in a

\footnotetext{
1 Identity of species verified by Mr. August Busck of the U. S. Bureau of Entomology, Washington, D. C.
} 
cocoon at the bottom of the jar beneath the felt, next to the glass. The underside of the cocoon was incomplete and the larva was in part visible through the glass. November 11, conditions about unchanged. November 14, larva within cocoon beneath felt had moulted (skin disposed as in the case of the other); soon after it became comatose and remained so, as far as could be observed, until the following May. November 18, the remaining and active individual was still at cocoon-making, but this time in still another location-at the bottom of the jar beneath the felt. November 21, could not be located, but when jar was brought closer to the light to facilitate the observation it came out of one of the previously constructed cocoons. November 25 , within a more or less incomplete new cocoon, close to the one which it forsook the 21st. November 28, had moulted again; came half way out of cocoon during observation but backed in again. December 2, left cocoon during observation. December 5, again within one of its former cocoons, and forsook it while observation was made. December 9, moving about freely. December 12, ditto. December 16, within a rather loosely-constructed cocoon on bottom of jar, beneath felt, like its comatose companion. December 19, cocoon more dense. December 24, had moulted once more-third time since its confinement. December 30, apparently comatose. Both larvæ, it should be said at this point, moulted once, in addition, after they had apparently become torpid, just when the writer cannot say, the cast skins, evidencing this, being found in the cocoons - at the hinder ends-the following spring, after the emergence of the adults. It is interesting to note that in the final moult the cephalic portion of the skin remains attached to the rest of the skin; the dorsal or upper surface of the former splits medianly and longitudinally and the larva either wriggles out, or else pushes the skin off over its anal end. The interior of the cocoons are lined with white silk.

The moth which developed from the more active larva emerged first and proved to be a male. It was first observed May 14 (1918). It died May 23. The other moth (female) emerged between May 24, and May 26. In both cases, the empty pupal skin projected in greater part beyond the end of the cocoon, as figured by Riley (Ins. Life, II, 1890).

Eggs were observed June 2, a. m., and they were numerous then. 
None were observed May 31. Oviposition continued to June 8, p. m., at the latest, and the total number counted was 99-51 up to June 2, a.m., 41 between 2, a.m. and 4, p. m., 7 between 4, p. m. and $8, \mathrm{p} . \mathrm{m}$. They were laid on the less compact or looser surface of the felt, and some were placed quite deeply among the loose fibers. Evidently they are not always placed singly, for in one instance a group of four was found, and several occurred in pairs. The moth died the evening of June 9. The eggs (infertile in this case) were white to the unaided eye and under an ordinary hand lens, but practically colorless when magnified more highly; oval to ovoid in shape, but a few were somewhat reniform, resembling a type of bean; surface somewhat roughened, marked with nearly spherical, squarish, or elongate shallow depressions, with very narrow intervening ridges. Whether the roughened surface, and the subreniform shape, was due to the age of the eggs-for on June 9, when they were examined, a large proportion had already collapsed-the writer cannot say, although, he might state, it did not appear so. Eighteen were measured and were found to be .49 to $.66 \mathrm{~mm}$. long and .27 to $.34 \mathrm{~mm}$. wide. The longest were generally the broadest.

The present record, it might be added, adds to the accumulating evidence, seemingly, that this species rather than Tinea pellionella Linn. (the case-making moth) is the more common species in the North.

How is the marked difference in degree of activity and sensitivity manifested by the larvæ to be explained? Is it a matter of individuality? Or, in view of the resulting difference in sex, is it a matter of sex?

\title{
ECOLOGICAL RELATIONS OF THE LEPIDOPTEROUS GENUS DEPRESSARIA (GECOPHORIDA).
}

\author{
By Miss Jay R. Traver, \\ Department of Entomology, Cornell University.
}

The members of a group of animals or plants, closely allied to one another in a systematic sense, may yet differ rather widely in their habits of life. While fitted for the same general type of environment, they nevertheless show considerable variation in their adap- 

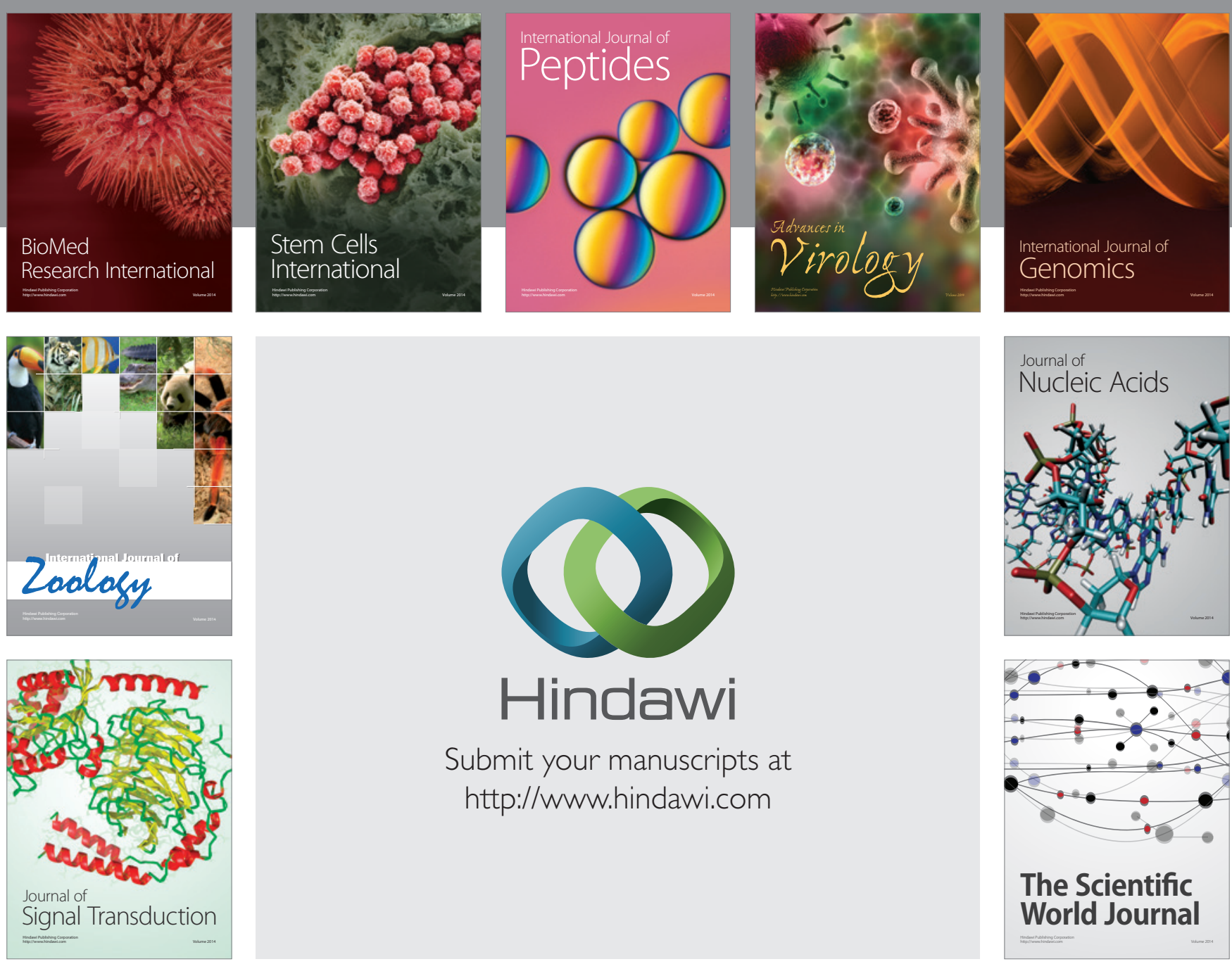

Submit your manuscripts at

http://www.hindawi.com
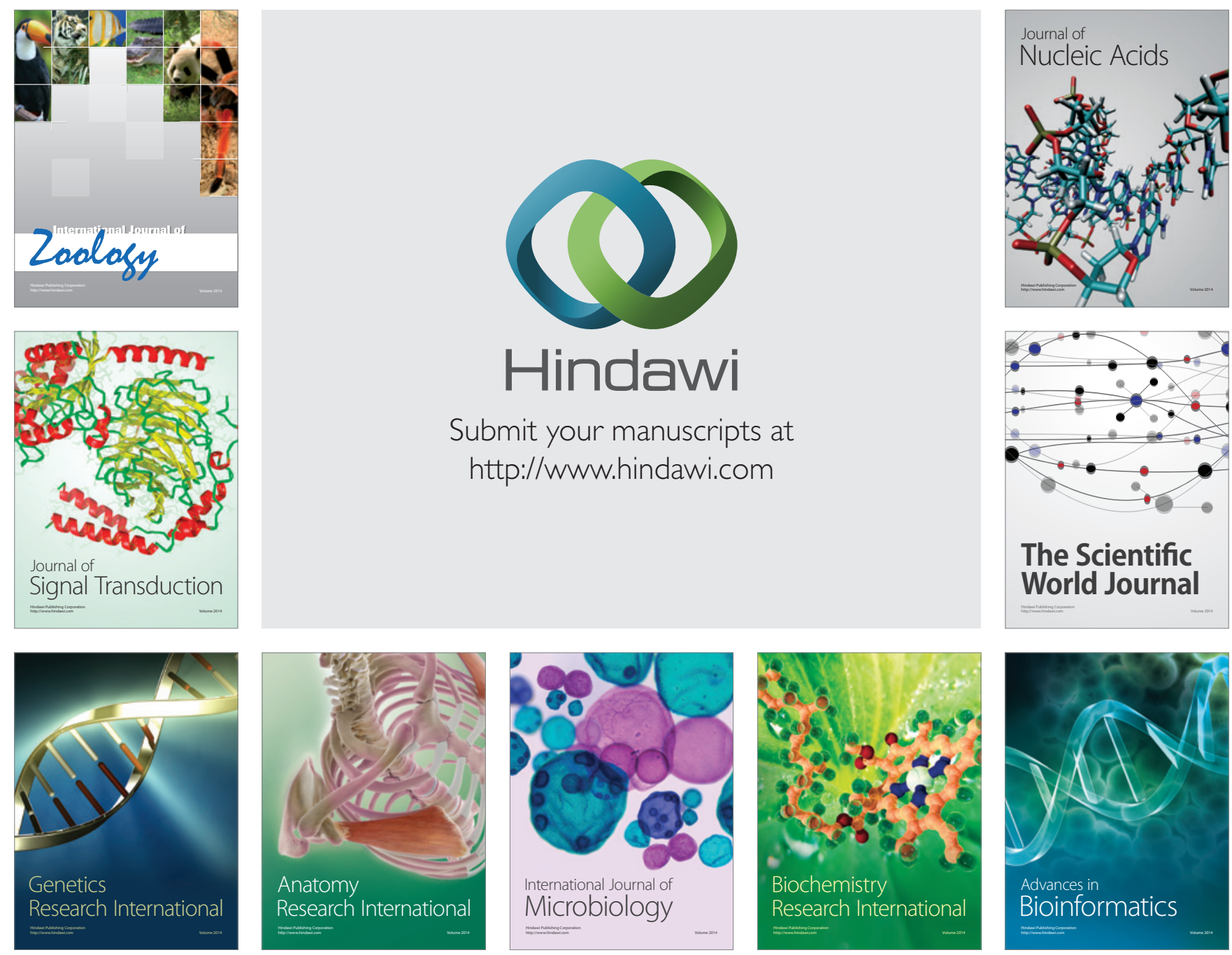

The Scientific World Journal
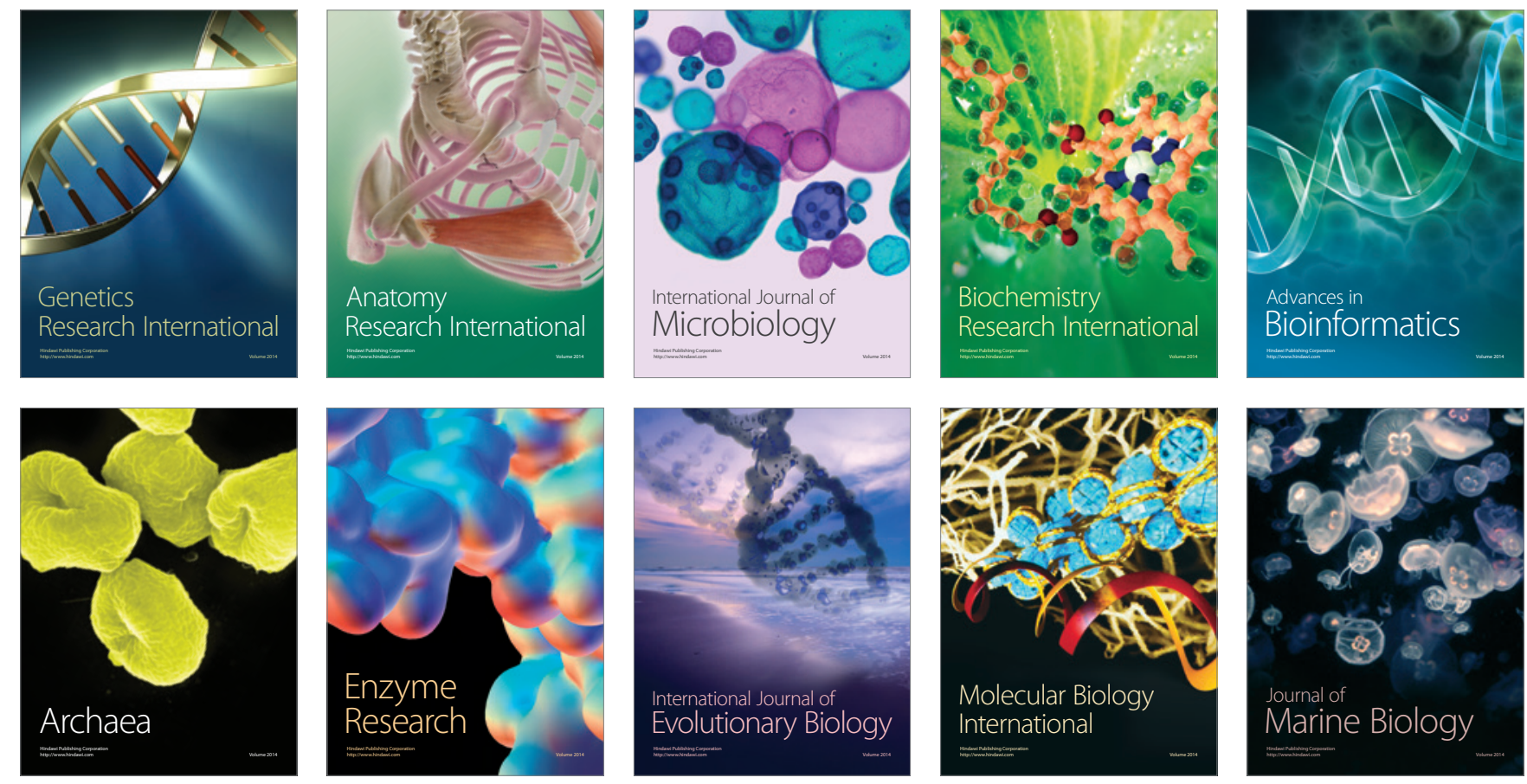